\title{
A new riparian Andean Potamites (Reptilia, Squamata, Gymnophtalmidae) from El Sira Mountains, central Peru, with comments on $P$. ecpleopus Cope 1875, and on the taxonomy and biogeography of Potamites
}

\author{
Germán CHÁVEZ ${ }^{\circledR 1, *}$, Jose MALQUI² \& Alessandro CATENAZZI ${ }^{\circledR 3}$ \\ ${ }_{1,3}^{1,3}$ Instituto Peruano de Herpetología, Lima, Peru. \\ 1,2,3 División de Herpetología-CORBIDI, Lima, Peru. \\ ${ }^{3}$ Department of Biological Sciences, Florida International University, Miami, USA. \\ ${ }^{*}$ Corresponding author: vampflack@yahoo.com \\ ${ }^{2}$ Email: josemalquiuribe@gmail.com \\ ${ }^{3}$ Email: acatenazzi@fiu.edu \\ ${ }^{1}$ urn:1sid:zoobank.org:author:9E8C7BD7-4A1B-469D-B54B-AE16D8DA2DD4 \\ ${ }^{2}$ urn:lsid:zoobank.org:author:B5FC3056-419C-4D87-B961-DA266C620E5D \\ ${ }^{3}$ urn:1sid:zoobank.org:author:DCC8463E-BD3F-4A19-99A3-1533D46E8A44
}

\begin{abstract}
We describe a new species of riparian lizard from the foothills and submontane forest of El Sira Communal Reserve, Departamento de Huánuco, Peru, at elevations from 540 to $760 \mathrm{~m}$. We name the new species Potamites hydroimperator sp. nov. because it is the only lizard living in streams in this isolated mountain. The new species is distinguishable from other congeners (except $P$. ecpleopus) by having longitudinal rows of keeled scales on dorsum, and males with 5-8 lateral ocelli on each flank. Potamites hydroimperator sp. nov. differs from P. ecpleopus by being smaller, having dorsal scales on forelimbs smooth or slightly keeled, subconical tubercles on forelimbs weakly present or absent, and four to five superciliar scales. We comment on variation in the pattern of keeling of dorsal scales among Amazonian lowland, Andean foothills and montane species of Potamites, and the potential relevance of this scalation pattern for taxonomic and biogeographic studies. The new species increases our knowledge of the diverse and endemic herpetofauna of El Sira, and of diversity within the genus Potamites. Despite El Sira's status as natural protected area, gold mining activities are destroying the streams where we found $P$. hydroimperator sp. nov., threatening their populations.
\end{abstract}

Keywords. Riparian, lizard, Potamites, Andean, Sira.

Chávez G., Malqui J. \& Catenazzi A. 2021. A new riparian Andean Potamites (Reptilia, Squamata, Gymnophtalmidae) from El Sira Mountains, central Peru, with comments on P. ecpleopus Cope 1875, and on the taxonomy and biogeography of Potamites. European Journal of Taxonomy 760: 136-159.

https://doi.org/10.5852/ejt.2021.760.1445 


\section{Introduction}

Over the last decade, molecular studies have helped resolve some mysteries in the taxonomy of gymnophtalmid lizards (Goicoechea et al. 2012, 2013; Torres-Carvajal et al. 2016; Kok et al. 2018; Moravec et al. 2018; Sánchez-Pacheco et al. 2018; Fang et al. 2020; Vasquez-Restrepo et al. 2020). These studies untied complicated knots in the systematics of Cercosaurinae Gray, 1838, especially in the genera Echinosaura Boulenger, 1890, Gelanesaurus Torres-Carvajal, Lobos, Venegas, Chávez, AguirrePeñafiel, Zurita \& Echevarría, 2016, Neusticurus Duméril \& Bibron, 1839, Proctoporus Tschudi, 1845, Potamites Doan \& Castoe, 2005, and Riama Gray, 1858. Among these studies, Torres-Carvajal et al. (2016) clarified the systematics of the genus Potamites, elevating Potamites trachodus Uzzell, 1966 (formerly a subspecies of $P$. strangulatus Cope, 1868) to a species level, and assigning $P$. cochranae Burt \& Burt, 1931 and P. flavogularis Altamirano-Benavides, Zaher, Lobo, Grazziotin, Sales Nunes \& Rodrigues, 2013 to the new genus Gelanesaurus. Therefore, the genus Potamites currently contains seven species: P. ecpleopus Cope, 1875, P. erythrocularis Chávez \& Catenazzi, 2014, P. juruazensis AvilaPires \& Vitt, 2001, P. montanicola Chávez \& Vasquez, 2012, P. ocellatus Sinitsin, 1930, P. strangulatus Cope, 1868, and P. trachodus Uzzell, 1966. Despite these efforts, delimitation of species of Potamites is still challenging (Moravec et al. 2018). The problems preventing the solution of the taxonomic knots of Potamites are lying mainly with its type species, P. ecpleopus. Uzzell (1966) reported the loss of the holotype of $P$. ecpleopus and the uncertainty regarding its type locality. Also, the original description is vague, and populations assigned to this species show a highly variable morphology (Uzzell 1966; AvilaPires 1995). Indeed, Uzzell (1966) reported a high degree of morphological variation in populations from Colombia, Ecuador and Peru, and Avila-Pires (1995) mentioned that samples from western Brazil resemble externally those from the Ecuadorian and Peruvian Amazon. In the same study, Avila-Pires found that the southern Peruvian populations studied by Uzzell are similar to those from Carajás (Pará, southern Brazil), but different from those from northern Brazil. Despite these taxonomically relevant findings, researchers were unable to identify traits of $P$. ecpleopus associated with geographic patterns that could inform the biogeography of this species. Unsurprisingly, the only consensus between these studies is that the skin of $P$. ecpleopus sensu stricto bears many tubercles, with tubercles present on dorsum, neck, flanks and tail (Uzzell 1966; Avila-Pires 1995). The paucity of reliable diagnostic traits complicated the taxonomy of $P$. ecpleopus, forcing scientists to be cautious in assigning a neotype.

Molecular phylogenies of the tropical Andean Cercosaurini revealed Potamites ecpleopus to be paraphyletic, with two geographically separated clades, one in the Ecuadorian Amazon and the other in the Peruvian and Brazilian Amazonia (Torres-Carvajal et al. 2016; Moravec et al. 2018). Because none of the sequenced $P$. ecpleopus correspond to specimens from the type locality or nearby areas, it was not possible to assign the name P. ecpleopus to either of these clades (Moravec et al. 2018). Indeed, one of the Peruvian samples included in these studies corresponds to a population of Potamites inhabiting the Andean foothills of El Sira Communal Reserve, an isolated chain of mountains about $450 \mathrm{~km}$ from the type locality (distance as the crow flies).

El Sira is a protected area located on the eastern slopes of the Andes in central Peru (see Fig. 1). The streams within the reserve drain into the middle basin of the Ucayali River, the longest tributary of the Amazon River in Peru. The landscape consists mainly of montane forest in the Andean foothills, interspersed with isolated and moderately high mountains (Duellman \& Toft 1979), where the topography goes from 200 to $2200 \mathrm{~m}$ a.s.l. (SERNANP 2010). The accidented topography makes El Sira Mountains quite hard to reach for scientific expeditions, which likely explains the low number of field expeditions to date. Strikingly, researchers discovered new species of amphibians and reptiles during each one of the previous expeditions (Duellman \& Toft 1979; Torres-Carvajal et al. 2015; Brown et al. 2019), suggesting the local herpetofauna is still partially unknown. 


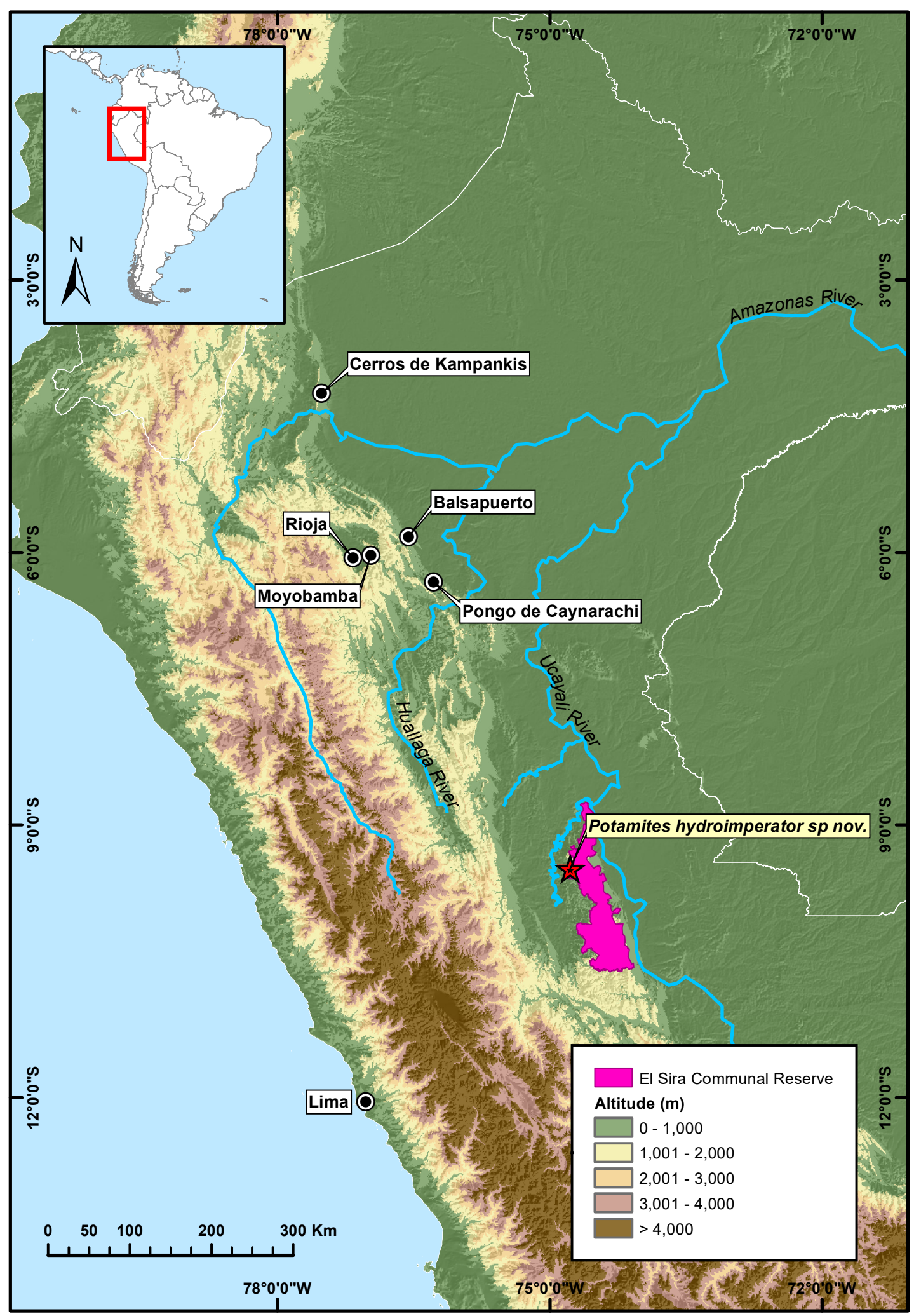

Fig. 1. Map showing the type locality of Potamites hydroimperator sp. nov. (red star), and the potential geographic distribution of $P$. ecpleopus Cope, 1875: Balsapuerto, Moyobamba, and Rioja, proposed by Uzzell (1966) adding Pongo de Caynarachi and Cerros de Kampankis as potential localities suggested herein. 
Finally, after performing morphological revisions and adding new sequences to the genetic data previously published, we conclude that Potamites lizards from El Sira, previously included in the analysis of TorresCarvajal et al. (2016) and Moravec et al. (2018), belong to an undescribed taxon that is morphologically distinguishable from congeners. Here we describe this new species of Potamites.

\section{Material and methods}

For the description format of the new species we followed Uzzell (1966), Vanzolini (1995), and AvilaPires \& Vitt (1998). For comparisons, we used the descriptions of all known species of Potamites in the literature: data for most Neusticurus and Potamites were taken from Uzzell (1966), data for P. juruazensis from Avila-Pires \& Vitt (1998), for P. ocellatus from Vanzolini (1995), and for P. erythrocularis, P. juruazensis, P. montanicola, and P. ocellatus from morphological revision of the respective type series (see Appendix 1). For morphological comparisons with P. ecpleopus we relied on data reported by Cope (1875), Uzzell (1966), and Avila-Pires (1995) as well as examined specimens (Appendix 1). We followed Uzell (1966) and Köhler \& Lehr (2004) for nomenclature of scale characters. We measured scale sizes using precision callipers and rounding to the nearest $0.1 \mathrm{~mm}$. For characters recorded on both sides, we presented the condition on the right side first. We fixed everted hemipenes with formalin 3.7\% (Zaher 1999) and followed Sánchez-Pacheco et al. (2018) for hemipenial terminology. We collected specimens at night while conducting opportunistic visual surveys. We euthanized specimens with T61 (Embrutamide), fixed them in $10 \%$ formalin, and stored them in $70 \%$ ethanol. Before fixation, we obtained tissue samples (liver) from all individuals and stored them in absolute ethanol.

We downloaded 12S, 16S, c-mos, and ND4 sequences of six of seven species currently assigned to Potamites (on the basis of BLAST) from GenBank and added two novel sequences to the dataset (see Appendix 2). We estimated genetic distances for the 12S, 16S, c-mos, and ND4 rRNA mitochondrial fragment (see Supp. files 1, 2, 3, 4) to provide further support of species delimitation.

All specimens captured for this study are covered by the permit RJ N ${ }^{\circ} 003-2014-S E R N A N P-R C S-$ JEF029-2016-SERFOR-DGGSPFFS issued by Servicio Nacional de Areas Protegidas de Peru which includes scientific collection of live individuals. We deposited specimens and tissue samples in the Herpetology Collection of Centro de Ornitología y Biodiversidad (CORBIDI). We used high-resolution photographs taken in the field to describe the coloration in life of the type series.

\section{Repositories}

The material upon which this study is based is located in the following institutions:

$\mathrm{AMNH}=$ American Museum of Natural History, New York, USA

CORBIDI $=$ Herpetology Collection of Centro de Ornitología y Biodiversidad, Lima, Peru

MPEG = Museu Paraense Emilio Goeldi, Belém, Brazil

MUSM = Museo de Historia Natural de la Universidad Nacional Mayor de San Marcos, Lima, Peru

\section{Abbreviations \\ $\mathrm{HL}=$ head length \\ HW = head width \\ SVL $=$ snout-vent length}

\section{Results}

\section{Generic allocation and species delimitation criteria}

Torres-Carvajal et al. (2016) examined the phylogenetic relationships of the new species and showed that the female CORBIDI 14382 (Genbank accession code KU902066) is part of a lineage within Potamites. We also add novel sequences to the genetic analysis (Appendix 2) which agreed with Torres-Carvajal 
et al. (2016) placing the new species into the Potamites as a separated clade. We estimated uncorrected $p$-distances with the R package 'APE' (Paradis et al. 2004) to support the specific delimitation of the new species from its congeners. Although there is not a set threshold for delimiting species, we use $2 \%$ distance for $12 \mathrm{~S}$ and $16 \mathrm{~S}$ which is even more than the standard cut-off value suggested by the BOLD (Barcode of Life Data) system as a reasonable criterion to identify putative new species (Ratnasingham \& Hebert 2007). The benefit of using 12S, 16S, c-mos, and ND4 sequences is that these fragments have been previously sequenced for Potamites lizards (Pellegrino et al. 2001; Torres-Carvajal et al. 2016; Moravec et al. 2018). Additionally, our morphological revision confirmed that other specimens collected in the same locality belong to the same taxon. Therefore, following de Queiroz $(1998,2007)$ and the unified species concept, we assign our sample to a new taxon into the genus Potamites.

\section{Taxonomy}

Phylum Chordata Haeckel, 1874

Class Reptilia Laurenti, 1768

Order Squamata Oppel, 1811

Family Gymnophtalmidae Merrem, 1820

Subfamily Cercosaurinae Gray, 1838

Genus Potamites Doan \& Castoe, 2005

Potamites hydroimperator sp. nov. urn:1sid:zoobank.org:act:2BA679E8-0E9B-496C-A03A-0C9C84DDD958

Figs 2-3, 4A-B, 5A-B, 7A, 8A; Table 1

Potamites ecpleopus - Torres-Carvajal et al. 2016: 70. See comments under 'Generic allocation'.

\section{Diagnosis}

A medium-sized Potamites ( $\mathrm{SVL}=50.5-59.6 \mathrm{~mm}, \mathrm{n}=5$ ) characterized by the following combination of morphological features: 1) Body slender, slightly depressed laterally, maximum SVL in males $59.6 \mathrm{~mm}$, $51.6 \mathrm{~mm}$ in females; 2) head acuminate from dorsal and lateral view, scales on the dorsal surface of the head smooth; 3) frontonasal divided, shorter than frontal, small rounded azygous scale usually present between frontonasal and prefrontals; 4) prefrontals present; 5) frontal present; 6) loreal present, romboid, not in contact with supralabials; 7) nasal partially divided, behind the nostril; 8) supraoculars four, anteriormost not fused with anteriormost superciliar; 9) superciliar series complete, usually five, occasionally four; 10) supralabial-subocular fusion absent; 11) lower palpebral disc oval, transparent, not divided; 12) postoculars three; 13) postparietals 10-11;14) hemipenis in two pairs, transverse sutures perpendicular with respect to midline of body; 15) dorsals rectangular, subimbricate, granular and keeled; 16) 34-36 longitudinal rows of dorsal keeled scales, 2-3 granular scales between the two paravertebral rows of keeled dorsals; 17) flanks partially covered by subconical low tubercles, absent or poorly present above the insertion of forelimbs; 18) anterolateral and dorsal brachial scales of forelimbs smooth or slightly keeled; 19) 32-36 scales around midbody; 20) 21-22 longitudinal rows of ventral scales; 21) 3233 total femoral pores in males, two in females, two scales between femoral pores; 22) 14-16 subdigital scales on $4^{\text {th }}$ finger; 23) $21-24$ on $4^{\text {th }}$ toe; 24) forelimb reaching anteriorly the fourth supralabial; 25) tail slightly compressed with three rows of lateral scales per two ventral caudals; 26) hemipenis globose (Supp. file 5), lobes indistinct from hemipenial body; 27) hemipenial flounces chevron shaped, lacking calcified spines, laterally oriented and forming two chevrons on distal half of hemipenis while its basal half is covered with four transverse flounces, separated by a small expansion pleat; sulcate flounces about as wide as asulcate flounces; isolated transversal flounces on proximal-central region of asulcate face absent; distal filiform appendages on the hemipenial lobes absent, sulcus spermaticus single; 28) dorsum yellowish brown to dark brown with slightly darker irregular blotches; 5-8 lateral ocelli with a creamy 
yellow center on each flank in males, a single ocellus with a pale brown center at the level of the insertion of forelimbs on each flank in females; flanks yellowish brown or partially pigmented of vermilion red in adult males; a creamy white to yellow diagonal stripe (continuous or discontinuous) going from $4^{\text {th }}$ or $5^{\text {th }}$ supralabials to $5^{\text {th }}$ infralabial; ventral coloration in males vermilion red to reddish pink on belly and base of the tail, yellowish pink on ventral surface on limbs, pale blue to grayish blue on ventral surface of the neck and throat, saffron yellow on femoral pores; ventral coloration in females creamy yellow on throat, chest, belly, ventral surface of limbs and base of the tail, with black speckling on throat; ventral surface of the rest of the tail yellowish brown to dark brown in males and females; pupil black surrounded by a yellowish orange to copper ring, iris olive to yellowish brown.

\section{Differential diagnosis}

The presence of longitudinal dorsal rows of keeled scales makes Potamites hydroimperator sp. nov. similar in appearance to populations of $P$. ecpleopus, a species widely distributed along the eastern Andean foothills and the Amazon (Uzzell 1966; Avila-Pires 1995; Ribeiro-Júnior \& Amaral 2016, 2017). Potamites hydroimperator sp. nov. can be distinguished from P. ecpleopus (characters for P. ecpleopus in parenthesis) by having low tubercles on flanks and above forelimbs (vs flanks strongly tuberculate, see Fig. 8A-C), anterodorsal region of forelimbs smooth or slightly keeled (vs strongly keeled, see Fig. 8A-C), 4-5 superciliars (vs 3-4, see Fig. 4A, C), a smaller size with males reaching a maximum SVL of $59.6 \mathrm{~mm}$ (vs $64.0 \mathrm{~mm}$, except for the Ucayali Valley population, where males reach $58.0 \mathrm{~mm}$ ), and the presence of 5-8 pairs of conspicuous lateral ocelli in males (vs 1-5 pairs of conspicuous lateral ocelli). The new species is easily distinguishable from P. erythrocularis, P. montanicola, P. ocellatus, and $P$. trachodus (Figs 5, 7), all of them inhabiting the Andean foothills and montane forests, by having longitudinal rows of keeled scales on dorsum (vs scattered or irregular rows of keeled scales), and males with 5-8 lateral ocelli on each flank (vs 1-5). Potamites hydroimperator sp. nov. shares with P. juruazensis the presence of an azygous scale behind frontonasal in the most of individuals (Fig. 4B, H), but is easily differentiable by having a larger SVL reaching $59.6 \mathrm{~mm}$ in males (vs $50 \mathrm{~mm}$ ), an acuminate head from lateral view (vs rounded), a longer count of total femoral pores, 32-33 in males and two in females (vs 10-16 in males, $0-1$ in females), numerous lateral ocelli in males and females (vs absent), and absence of small scales between frontal and frontoparietals (vs two or three small scales, see Fig. 4B, H). Finally, P. hydroimperator sp. nov. differs from $P$. stangulatus by having rows of keeled scales on neck and dorsum (vs low not keeled dorsal scales, see Fig. 5A-B, K-L), a smaller count of transverse rows of dorsals with 34-36 (vs 55-90), and by having a smaller number of total femoral pores, 32-33 in males and two in females (vs 54-55 in males, 6-10 in females).

\section{Etymology}

The specific epithet 'hydroimperator' derives from the Greek word 'hydro' ('water'), and the Latin name 'imperator' ('emperor'). The name alludes to the riparian habits of the new species, which is the only lizard in El Sira using the streams as part of its habitat.

\section{Material examined}

Holotype

PERU - adult đ̊; Departamento de Huánuco, Puerto Inca Province, El Sira Communal Reserve, Campamento Hospital (on the trail to the top of El Sira Communal Reserve); $9.478667^{\circ} \mathrm{S}, 74.778139^{\circ} \mathrm{W}$; 757 m a.s.1.; 28 Nov. 2013; G. Chávez leg.; CORBIDI 13915 (Figs 2, 4A-B, 7A).

Paratypes $(n=4)$

PERU - 1 adult +; same locality data as for holotype; 21 Mar. 2014; G. Chávez and J. Malqui leg.; Genbank accession code KU902066; CORBIDI 14382 • 2 adult $\widehat{\jmath}$; Departamento de Huánuco, Puerto Inca Province, El Sira Communal Reserve, Campamento Caoba (on the trail to the top of El Sira 

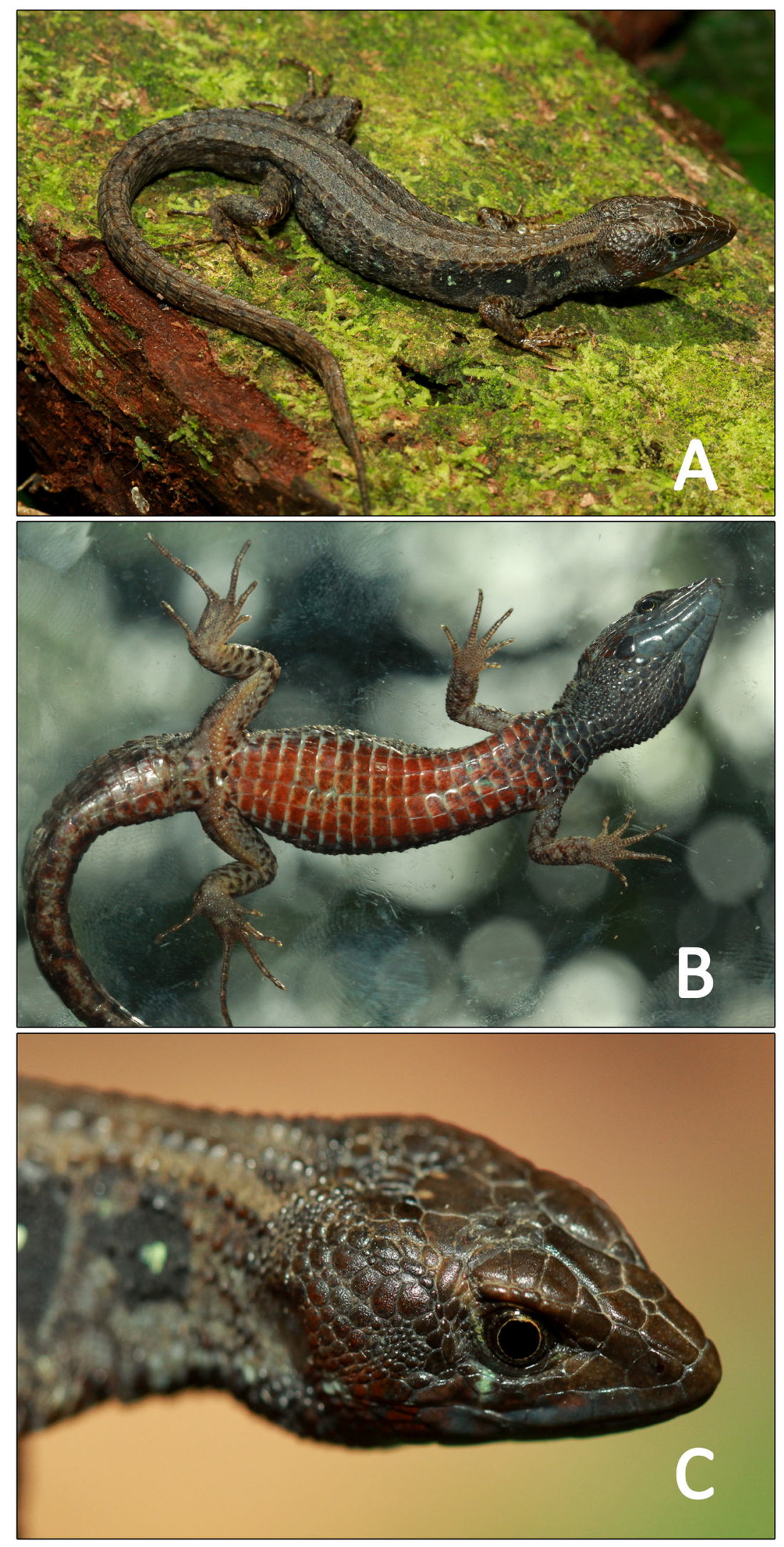

Fig. 2. Holotype in life of Potamites hydroimperator sp. nov., CORBIDI 13915 (SVL = $59.4 \mathrm{~mm}$ ). A. Dorsal view. B. Ventral view. C. Dorsolateral view of the head. 
Communal Reserve); $9.502194^{\circ} \mathrm{S}, 74.80425^{\circ}$ W; 545 m a.s.1.; 28 Mar. 2014; G. Chávez and J. Malqui leg.; CORBIDI 14468 to 14469 (Figs 3A-D, 5A-B) • 1 adult $\%$; same collection data as for preceding; CORBIDI 14470 (Fig. 3E-F).

\section{Description (holotype)}

The holotype is adult male CORBIDI 13915 (Figs 2, 4A-B, 7A). Body long, laterally compressed, SVL $59.4 \mathrm{~mm}$; tail (complete) length $81.7 \mathrm{~mm}$, axilla to groin distance $27.8 \mathrm{~mm}$; head length $16.1 \mathrm{~mm}$; head width $10.0 \mathrm{~mm}$; shank length $9.7 \mathrm{~mm}$. Head scales smooth; rostral scale wider $(2.2 \mathrm{~mm})$ than long $(1.1 \mathrm{~mm})$, higher than adjacent supralabials, in contact with frontonasal, nasal, and first supralabials posteriorly; frontonasal divided, almost squarish, slightly wider $(2.2 \mathrm{~mm})$ than longer $(2.1 \mathrm{~mm})$, widest posteriorly,
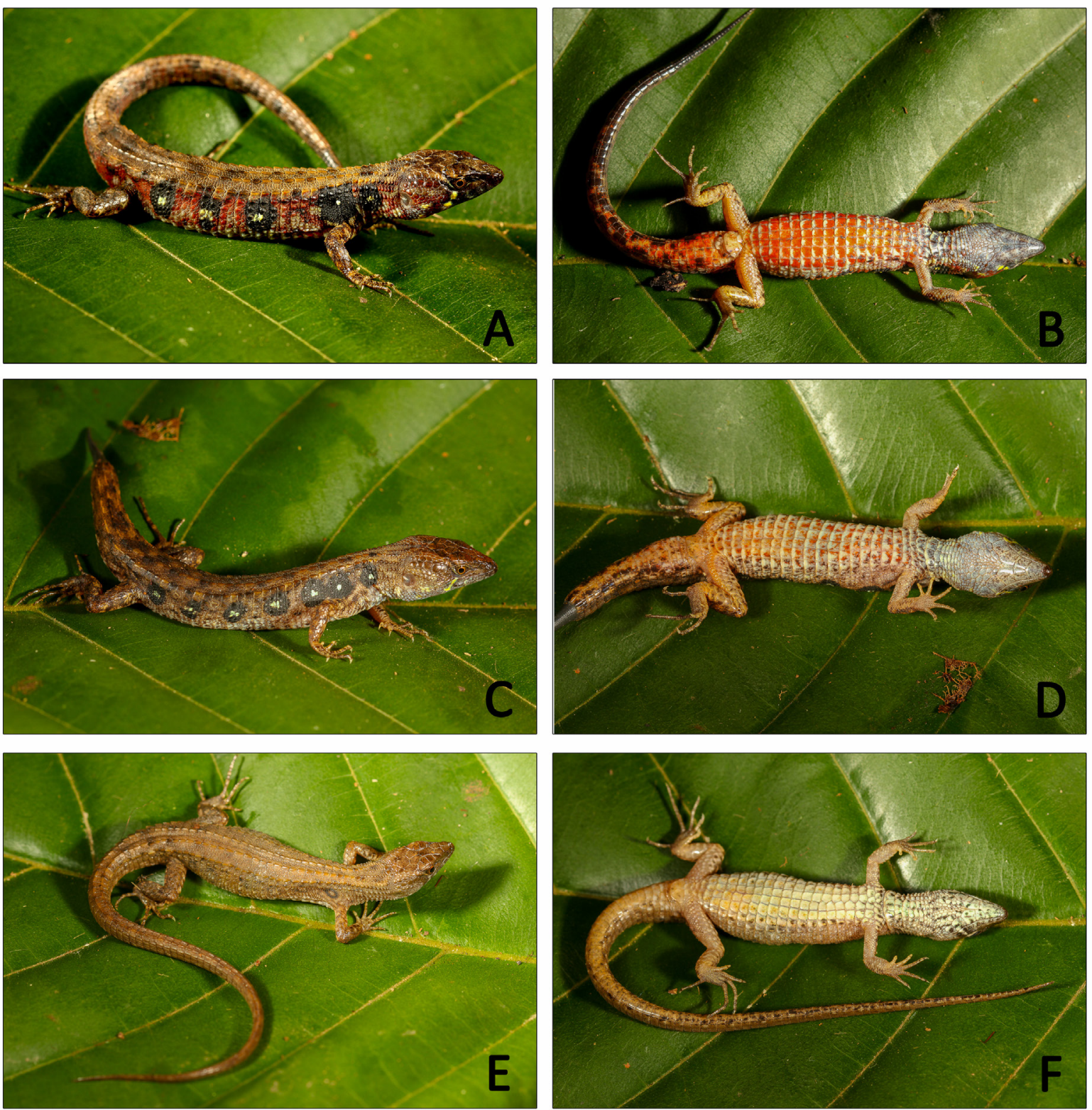

Fig. 3. Variation of the type series showing the dorsal (left column) and ventral (right column) views of paratypes. A-B. $\overbrace{}^{\lambda}$, CORBIDI $14468(\mathrm{SVL}=54.5)$. C-D. ${ }^{\lambda}$, CORBIDI $14469(\mathrm{SVL}=59.6)$. E-F. ㅇ, CORBIDI $14470(\mathrm{SVL}=51.6)$. 
in contact with nasoloreal and frenocular laterally, and azygous scale and prefrontals posteriorly; azygous scale between frontonasal and prefrontals rhomboid, about four times smaller than frontonasal, in contact anteriorly with posterior edge of frontonasal and posteriorly with anterior edge of prefrontals; nasal almost triangular, apex in contact with rostral, nasoloreal suture present, incomplete; prefrontals present, in contact with each other medially, in contact with anteriormost superciliary and anteriormost supraocular, frontal posteriorly; frontal longer $(3.1 \mathrm{~mm})$ than wider $(1.9 \mathrm{~mm})$, anterior suture angular with point directed anteriorly, lateral sutures straight, posterior suture angular with point slightly directed posteriorly, in contact with first, second, and third supraocular laterally, frontoparietals posteriorly; frontoparietals pentagonal, in contact with third and fourth supraocular, parietals and interparietal posteriorly; supraoculars four, none in contact with ciliaries; superciliary series complete, five, anteriormost superciliary not fused with anteriormost supraocular; interparietal pentagonal, slightly longer $(3.0 \mathrm{~mm})$ than wider $(2.8 \mathrm{~mm})$, in contact with parietals laterally, postparietals posteriorly; parietals pentagonal, in contact with fourth supraocular anterolaterally, dorsalmost postocular, postparietals posteriorly; postparietals 13, polygonal, boardering parietals and interparietal; palpebral disc an undivided oval, unpigmented; loreal rhomboid, not in contact with supralabials; frenocular pentagonal, in contact with nasal anteriorly; postoculars three; temporals polygonal, of a medium size; supralabials six; infralabials five; mental wider $(1.9 \mathrm{~mm})$ than long $(1.3 \mathrm{~mm})$, in contact with first infralabials, postmental posteriorly; postmental single, slightly wider $(2.6 \mathrm{~mm})$ than long $(2.5 \mathrm{~m})$, pentagonal, posterior suture angular, point directed posteriorly, in contact with first and second infralabials; genials in two pairs, anterior pair subquadrangular, in contact with

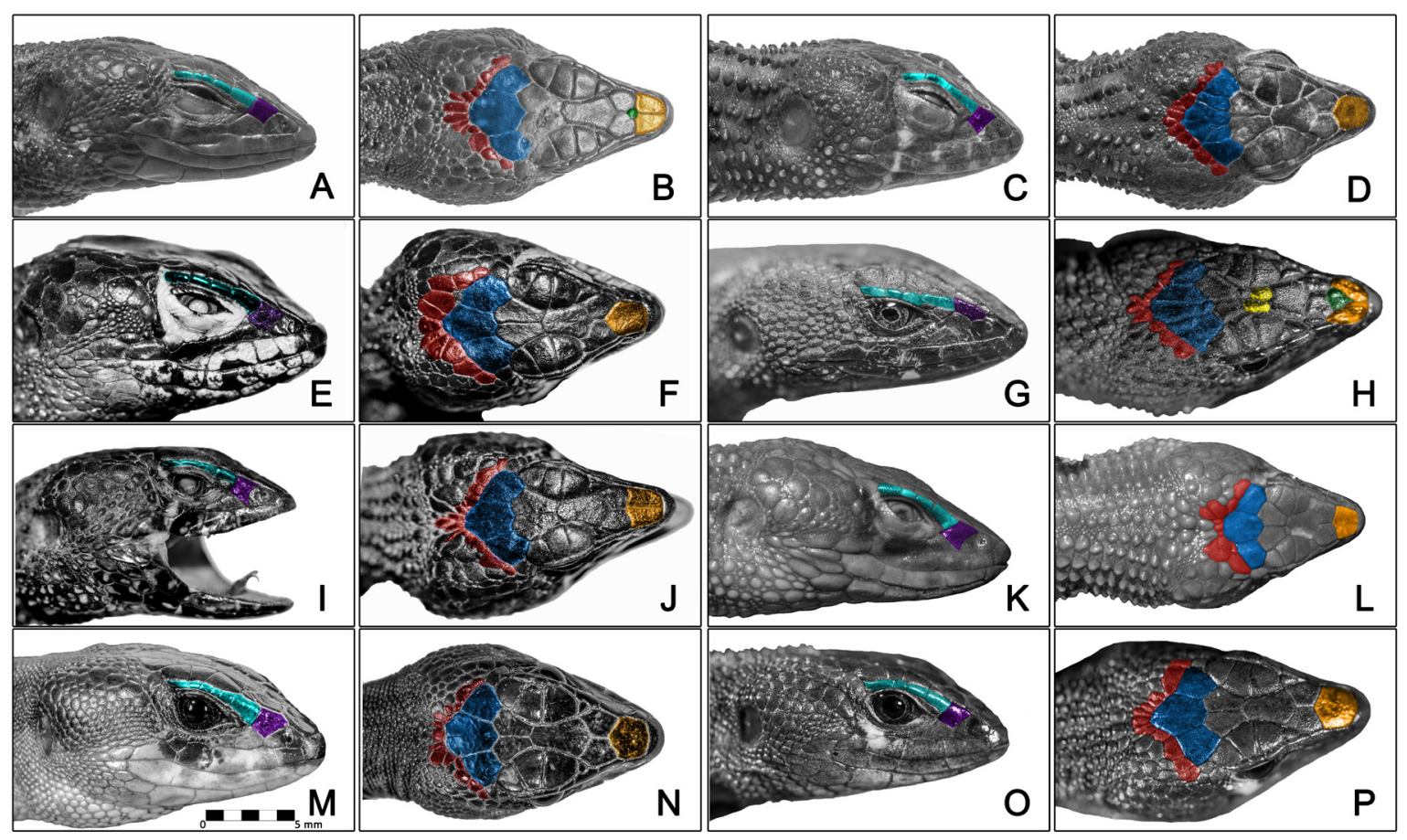

Fig. 4. Lateral (left columns) and dorsal (right columns) views of the head of all species of Potamites Doan \& Castoe, 2005, showing condition of superciliars (turquoise), loreal (purple), frontonasals (yellow), parietals and interparietal (blue), postparietals (red), and azygous scales (green). A-B. P. hydroimperator sp. nov. (CORBIDI 13915, holotype). C-D. P. ecpleopus Cope, 1875 (CORBIDI 9059). E-F. P. erythrocularis Chávez \& Catenazzi, 2014 (MUSM 28056, holotype). G-H. P.juruazensis Avila-Pires \& Vitt, 2001 (CORBIDI 15504). I-J. P. montanicola Chávez \& Vasquez, 2012 (CORBIDI 8322, holotype). K-L. P. ocellatus Sinitsin, 1930 (AMNH 22512, holotype). M-N. P. strangulatus Cope, 1868 (CORBIDI 11415). O-P. P. trachodus Uzzell, 1966 (CORBIDI 15515). 
second and third infralabials; posterior genials pentangular, in contact with third and fourth infralabials laterally; scale rows between genials and collar fold (along midventral line) 16; posteriormost gular row enfolded posteriorly, concealing two granular scale rows; lateral neck scales rounded, conical. Dorsal scales both granular and keeled, a longitudinal row of dorsolateral tubercle scales on both sides, tubercles posteriorly projected, dorsal keeled scales 35 in a longitudinal count, forming four rows from post occipital region to posterior edge of insertion of hindlimbs, separated by granular scales; lateral scales on body near insertion of forelimb small, conical dorsally, mostly granular; ventrals squarish and juxtaposed; complete longitudinal ventral count 21; longitudinal ventral scale rows at midbody seven; 41 scales around midbody; anterior preanal plate scales two; posterior preanal plate scales three, arranged in a row, central smaller and triangular, pointed posteriorly, in contact distally and posteriorly with scales at both sides, scales at sides hexagonal, larger than central preanal, contacting each other behind central preanal; dorsal and dorsolateral surface of tail with at least 64 whorls of enlarged keeled scales; midventral subcaudals squarish, smooth. Limbs pentadactyl; digits clawed; forelimb reaching
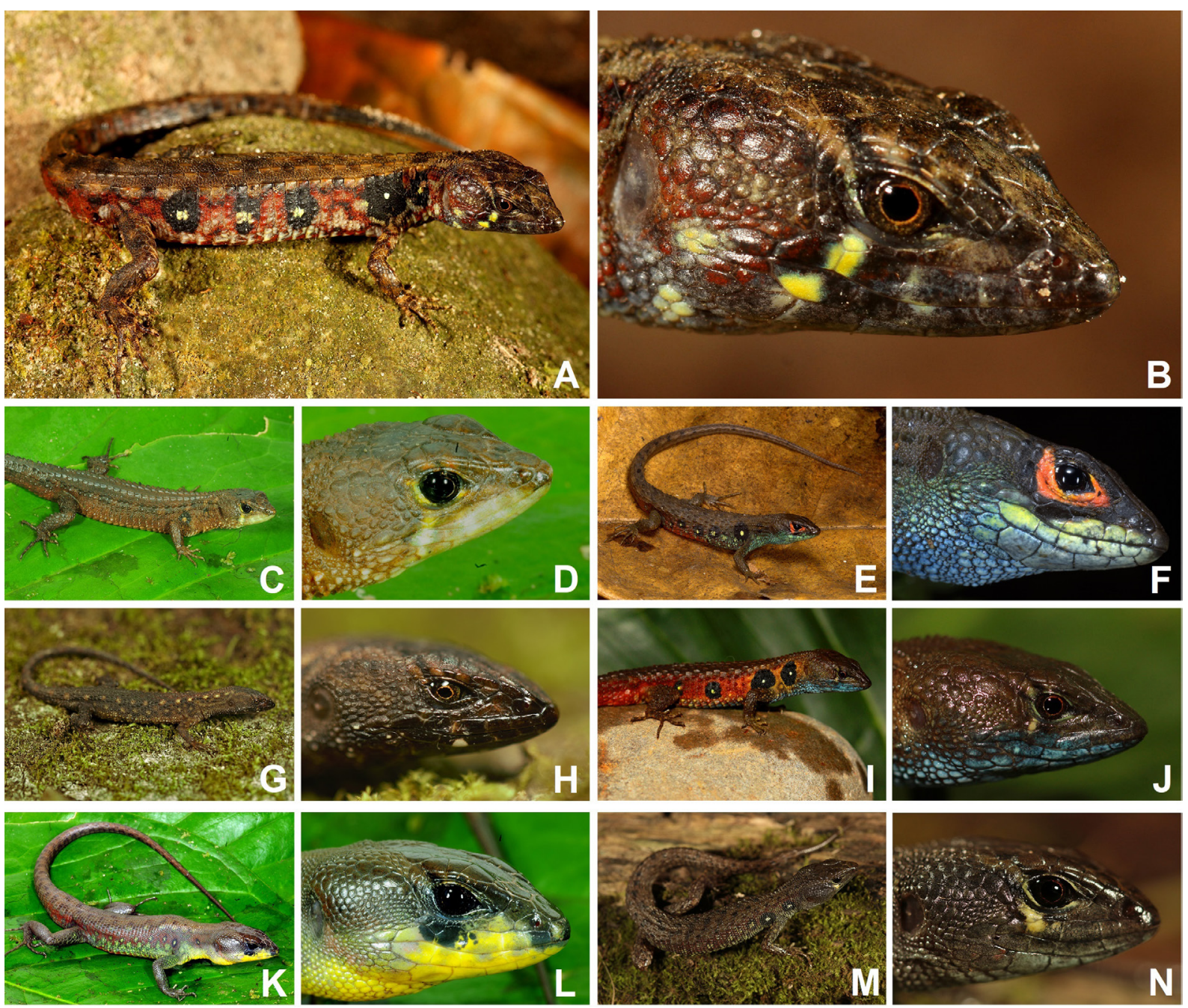

Fig. 5. Coloration in life of males of all species of Potamites Doan \& Castoe, 2005 ocurrying in Peru. A-B. P. hydroimperator sp. nov. (CORBIDI 14468). C-D. P. ecpleopus Cope, 1875 (CORBIDI 9516). E-F. P. erythrocularis Chávez \& Catenazzi, 2014 (MUSM 30260). G-H. P.juruazensis Avila-Pires \& Vitt, 2001 (CORBIDI 15504). I-J. P. montanicola Chávez \& Vasquez, 2012 (CORBIDI 10596). K-L. P. strangulatus Cope, 1868 (CORBIDI 11415). M-N. P. trachodus Uzzell, 1966 (CORBIDI 15515). Photographs by Germán Chávez (A-B, G-J, M-N) and Alessandro Catenazzi (C-F, K-L). 
anteriorly to fifth infralabial; anterolateral and dorsal brachial scales smooth or slightly keeled, imbricate; midbrachial anterodorsal scale at least twice as large as adjacent scales, slightly keeled; anteroventral, ventral, and posteroventral scales granular, imbricate; antebrachial scales polygonal, slightly keeled; medial antebrachial scales small, polygonal, smooth; dorsal manus scales polygonal, imbricate, smooth; palmar scales small, polygonal, smooth; dorsal scales on fingers smooth, quadrangular, covering dorsal half of digit, overhanging supradigital scales, two on I, seven on II, eight on III, eleven on IV, six on V; subdigital scales $6 / 5$ on I, 11/10 on II, 14/15 on III, 17/16 on IV, nine on V; dorsal thigh scales granular, slightly tuberculate, some scales bearing conical tubercles, anterodorsal thigh scales polygonal, larger than adjacent scales, slightly keeled; posterodorsal thigh scales small, granular, dorsalmost scales slightly tuberculate, arranged irregularly, ventral thigh scales polygonal, smooth, smaller than anterodorsal thigh scales and reducing distally; anterior and anteromedial shank scales granular, imbricate, tuberculate, anteriormost scales at the same size as lateral, posterolateral, and posteromedial shank scales; lateral, posterolateral, and posteromedial shank scales granular, imbricate, some bearing conical tubercle; scales on dorsal surface of digits single, quadrangular, smooth, overhanging supradigital scales, four on I, eight on II, 11/12 on III, 16/17 on IV, 9/10 on V; subdigital scales single or double, 9/10 on I, 10/11 on II, $16 / 17$ on III, $24 / 25$ on IV, $11 / 12$ on V; total femoral pores 33 (17/16). The completely everted hemipenis is an acapitate organ without a medial welt; apex with two large protrusions separated by the distal end of the sulcus spermaticus; sulcus spermaticus single, flounces lacking calcified spines and forming two chevrons on distal half of hemipenis; sulcate flounces about as wide as asulcate flounces; asulcate flounces becoming shorter distally, three in the basal half and sixteen in each protrusion, distal chevrons separated by a small expansion pleat; sulcus spermaticus single, flanked by a broad naked expansion pleat widened distally.

\section{Coloration in life}

Dorsal and lateral surfaces of head brown to dark brown (Fig. 2C); rostral scale same colour as head; superior labium bluish grey with pale red irregular blotches on third, fourth, and fifth supralabials, irregular vermilion red blotches on sixth and seventh supralabials, an irregular diagonal pale yellow stripe going from fourth supralabial to superior edge of fifth infralabial; infralabials grayish blue, pale red faded blotches on fifth infralabial, and a vermilion red patch on sixth infralabial; iris olive yellow, with a copper orange ring surrounding pupil; throat and gular region greyish blue, darker on ventral surface of neck. Dorsal surface of body yellowish brown, with some darker areas; coloration on flanks yellowish brown with eight black ocelli on both sides, going from neck to base of tail (after insertion of forelimbs), each ocelli bearing a white center; tuberculate scales darker than granular scales; belly vermilion red. Dorsal surface of limbs similar to body, ventral surface of arms and legs pinkish cream; femoral pores saffron yellow. Coloration of dorsal surface of tail like that of body, ventral surface of tail pinkish cream with irregular red blotches at base, and a darker flecking pattern on rest of tail.

\section{Coloration in preservative}

General coloration pattern is as described for the holotype in life. Dorsal coloration is mostly brown, with labial region greyish brown, throat yellowish brown, chest dark brown and venter creamy yellow. Flanks yellowish brown, lateral ocelli present. Ventral surfaces of forelimbs pale yellow with black blotches; ventral surfaces of limbs creamy yellow with dark speckling; ventral surface of tail brownish yellow with diffuse dark speckling.

\section{Taxonomic remarks}

Females CORBIDI 14382 and 14470 (Fig. 3 E-F) have four superciliars. The frontonasal scale is partially divided in male CORBIDI 14469 (Fig. 3 C-D). Furthermore, the azygous scale between the frontonasal and prefrontals is absent in male CORBIDI 14469 (Fig. 3C-D) and female CORBIDI 14470 (Fig. 3EF). We described colour pattern variation of the type series in the diagnosis. Other measurements and scutellation data of the type series are summarized in Table 1. 
Table 1. Measurements (in $\mathrm{mm}$ ) and scutellation of the type series of Potamites hydroimperator sp. nov.

\begin{tabular}{lccccc}
\hline & $\begin{array}{c}\text { CORBIDI } \\
\mathbf{1 3 9 1 5} \\
\text { (holotype) }\end{array}$ & $\begin{array}{c}\text { CORBIDI } \\
\mathbf{1 4 4 6 8}\end{array}$ & $\begin{array}{c}\text { CORBIDI } \\
\mathbf{1 4 4 6 9}\end{array}$ & $\begin{array}{c}\text { CORBIDI } \\
\mathbf{1 4 4 7 0}\end{array}$ & $\begin{array}{c}\text { CORBIDI } \\
\mathbf{1 4 3 8 2}\end{array}$ \\
\hline Sex & Male & Male & Male & Female & Female \\
Snout-vent length & 59.4 & 54.5 & 59.6 & 51.6 & 50.5 \\
Head length & 16.1 & 15 & 16.2 & 13.7 & 12.8 \\
Head width & 10.0 & 9.9 & 10.3 & 8.2 & 7.5 \\
Axilla to groin distance & 27.8 & 25.0 & 28.4 & 24.2 & 24.5 \\
Tail length & 81.7 & 76.6 & 27.9 & 95 & 12.9 \\
Number of supralabials & $7 / 7$ & $7 / 6$ & $7 / 7$ & $7 / 7$ & $7 / 7$ \\
Number of transverse rows of dorsals & 35 & 35 & 36 & 35 & 34 \\
Number of scales around midbody & 41 & 43 & 41 & 43 & 43 \\
Number of transverse rows of ventrals & 21 & 21 & 22 & 21 & 21 \\
Number of longitudinal rows of ventrals & 7 & 8 & 7 & 8 & 8 \\
Number of preanals & 3 & 3 & 3 & 3 & 3 \\
Lamellae under finger IV & $16 / 16$ & $15 / 16$ & $14 / 15$ & $15 / 16$ & $16 / 16$ \\
Lamellae under toe IV & $24 / 23$ & $21 / 21$ & $24 / 23$ & $21 / 20$ & $24 / 24$ \\
Femoral pores & $17 / 16$ & $16 / 16$ & $17 / 17$ & $1 / 1$ & $1 / 1$ \\
HL/SVL & 0.2 & 0.2 & 0.2 & 0.2 & 0.2 \\
HW/SVL & 0.1 & 0.1 & 0.1 & 0.1 & 0.1 \\
HW/HL & 0.6 & 0.6 & 0.6 & 0.5 & 0.5 \\
\hline
\end{tabular}

\section{Distribution and ecology}

We observed the new species in streams and surrounding vegetation in two nearby sites, in the eastern slopes of the mountains of El Sira Communal Reserve, from 550 to 750 m a.s.l. (Fig. 1). These streams drain into the Pachitea River, which is a tributary of the Ucayali River. The habitat is a montane forest (Fig. 6), with riparian vegetation consisting mainly of bushes, tree ferns and trees canopy $\sim 20 \mathrm{~m}$ tall. Climbers are also present (lianas) as well as low epiphytes, ferns, mushrooms, and lichens on the ground and on rocks alongside the streams. We found lizards at night by lifting rocks or removing vegetation near stream banks. The male CORBIDI 14468 and the female CORBIDI 14470 used the stream to escape from the field researchers. We observed the new species in sympatry with the lizards Anolis cf. fuscoauratus, Enyaloides laticeps Guichenot, 1855, Iphisa elegans Gray, 1851, Potamites cf. juruazensis and the snakes Bothrocophias microphtalmus Cope, 1875, Dipsas catesbyi Sentzen, 1796, Dipsas pavonina Schlegel, 1837, and Xenoxybelis argentea Daudin, 1803. None of these squamates were found in water. On the basis of known diet habits and previous reports (Dueñas \& Valencia 2018), we regard B. microphtalmus as a potential predator of Potamites hydroimperator sp. nov.

\section{Discussion}

Torres-Carvajal et al. (2016) examined the phylogenetic relationships of Potamites, and assigned the new species to a lineage distinct from P. ecpleopus from lowlands and foothills of southern Ecuador. Moreover, inclusion of novel sequences from the Peruvian Amazon and Andean foothills confirms this hypothesis (Moravec et al. 2018; this study). In the phylogeny published by Torres-Carvajal et al. (2016), a Brazilian specimen appears to be closely related to the new species. The genetic sequences belong to a specimen from Apiacás, Mato Grosso, southern Brazil (Pellegrino et al. 2001), more than $400 \mathrm{~km}$ as the crow flies from the type locality of $P$. hydroimperator $\mathrm{sp}$. nov. Because we were not able to examine this specimen and its divergent distribution, we do not include it into the new taxa described herein. We recommend further genetic and morphological analyses to confirm the relationships of the specimens from Apiacás, Brazil with the new species and other lineages of the Potamites ecpleopus complex. Thus, 
the inferred genetic divergence, morphological traits (showing several differences with $P$. ecpleopus), and the restricted distribution range (on a mountain ridge known to harbor endemic species) support the validity of $P$. hydroimperator sp. nov. as a new taxon.

Alpha taxonomy within Potamites is far from being solved. Despite recent studies that improved our knowledge of Peruvian montane species (i.e., descriptions of P. erythrocularis and P. montanicola) and of evolutionary relationships among species of Potamites (Torres-Carvajal et al. 2016), populations from the Andean foothills and Amazon lowlands are still a taxonomic puzzle. For example, the taxonomy of P. ecpleopus, the type species of the genus, remains ambiguous. Previous genetic studies have suggested that populations of P. ecpleopus are polyphyletic, and that the group is a species complex (Torres-Carvajal et al. 2016; Moravec et al. 2018). Uzzell (1966) suggested that the type locality was somewhere between Rioja, Moyobamba and Balsapuerto (Peru), three sites less than $70 \mathrm{~km}$ apart lying on the Andean foothills of the Huallaga River drainage, with no geographical barriers separating them (Fig. 1). Therefore, we may assume that the type series of $P$. ecpleopus belongs to a population from the Andean foothills. In order to make proper comparisons, we have reviewed individuals recorded in the Andean foothills of Yurimaguas, Pongo de Caynarachi, and Cerros de Kampankis (Fig. 8B-C), all sites near the 'type locality' area (Fig. 1). We concluded that these populations share the phenotypic pattern and scutellation described by Cope (1875), Uzzell (1966) and Avila-Pires (1995) recognizing P. ecpleopus as one of the most tuberculate species among the genus. Indeed, we noted flanks and forelimbs themselves are highly keeled as described by Uzzell (1966). Otherwise, we have not observed similar condition in these traits in $P$. hydroimperator sp. nov. Additionally, our $16 \mathrm{~S}$ genetic analysis shows a $2-7 \%$ distance between Kampankis samples and the new species (see Appendix 2 and Supp. files 1, 2, 3, 4). On the basis of this

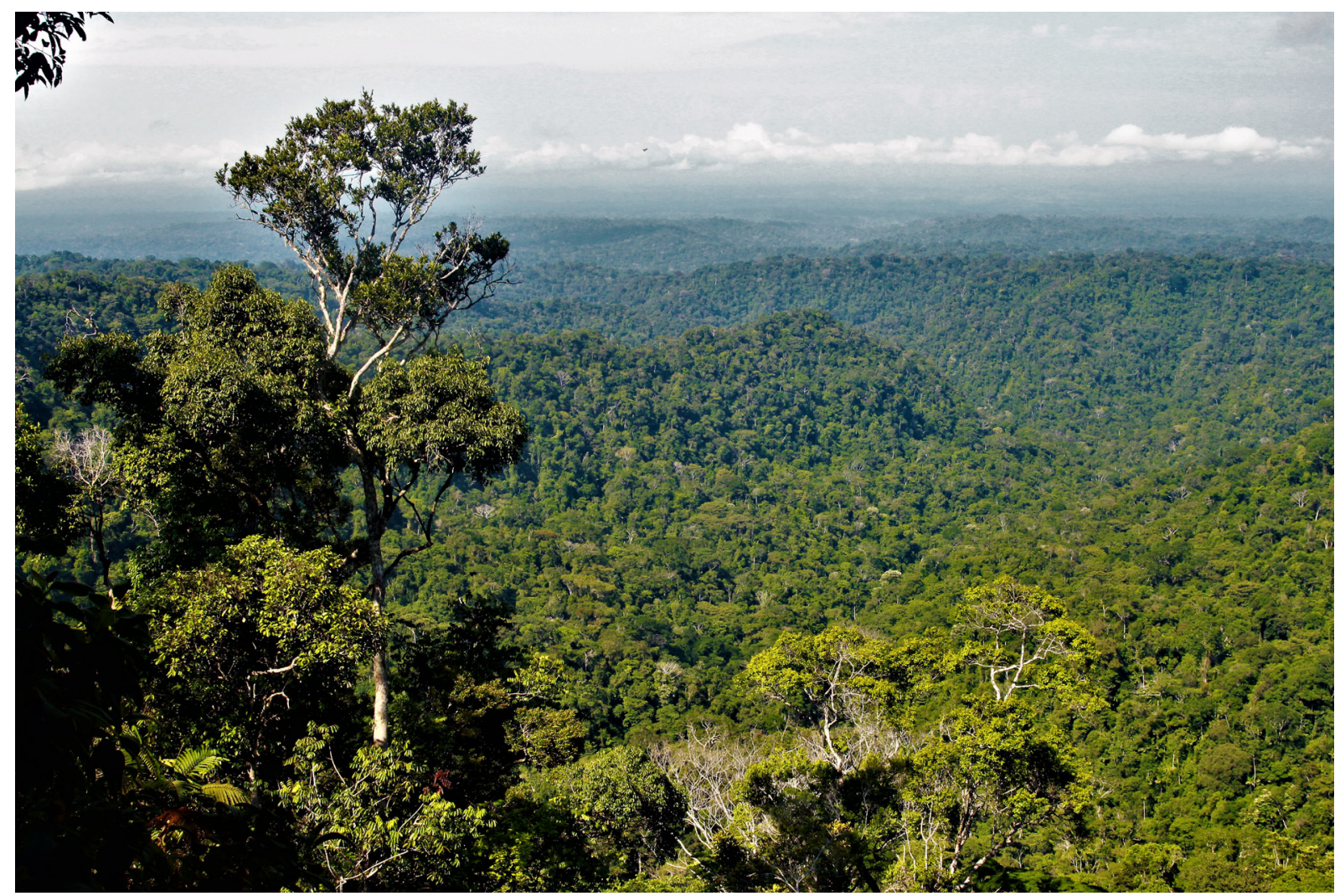

Fig. 6. Panoramic view of the primary forest on the mountains of the type locality of Potamites hydroimperator sp. nov. in El Sira Communal Reserve. 
evidence, it is possible to assign specimens we examined from Yurimaguas, Pongo de Caynarachi and Cerros de Kampankis to P. ecpleopus sensu Uzzell (1966).

In his comprehensive study of the Potamites lizards, Uzzell (1966) considered $P$. ocellatus as a junior synonym of $P$. ecpleopus, after reviewing the paratypes from Chanchamayo, Central Peru. Later Vanzolini (1995) revalidated P. ocellatus based on the holotype from Rurrenabaque, El Beni, Bolivia. Also, Vanzolini (1995) noticed that the strongly keeled dorsum and the scattered arrangement of the tubercles on the body of the paratypes contrast with the holotype morphology. Thus, the paratypes of $P$. ocellatus from Chanchamayo were assigned to P. ecpleopus (Uzzell 1966; Vanzolini 1995). The scattered arrangement of dorsal keels or tubercles is a diagnostic character for the recently described and well-supported montane species P. erythrocularis and P. montanicola (Chávez \& Vásquez 2012; Chávez \& Catenazzi 2014; TorresCarvajal et al. 2016; Moravec et al. 2018). A scattered arrangement of dorsal keels or tubercles is not seen in P. ecpleopus sensu lato. Therefore, we consider unlikely that the specimens from Chanchamayo could belong to any form of $P$. ecpleopus. Instead, we suggest that further genetic analysis should be performed to solve their taxonomic status.

As mentioned above, scattered keeled dorsals is a character previously reported for $P$. erythrocularis and P. montanicola (Fig. 7C and Fig. 7E respectively), two species inhabiting streams between 1000$2600 \mathrm{~m}$ a.s.1., and for P. ocellatus (Fig. 7F), the other montane species of this genus. Otherwise, the other Andean foothills species of Potamites bear scattered keeled dorsals (i.e., P. trachodus) or aligned rows (i.e., P. ecpleopus and P. hydroimperator sp. nov.). Finally, Amazon lowlands species such as $P$. juruazensis and lowland populations of $P$. ecpleopus have longitudinal aligned rows of dorsal keeled scales (Fig. 7D). Ecologically, Andean populations experience colder environments (water temperature in streams range between 3 and $12^{\circ} \mathrm{C}$ ) and stronger water velocity in streams than lowland Potamites. Ecological differences might have contributed to montane species evolving different patterns of dorsal keels from lowland populations (scattered keels in montane species, longitudinally aligned in lowland species). Considering that environmental conditions are more similar between montane forests and foothills ecosystems, dorsal keeling in Andean foothill populations could be variable, as exemplified by P. trachodus having scattered keeles, and $P$. hydroimperator sp. nov. having aligned rows.

The recent discovery of several montane species highlights the importance of the Andes for speciation of Potamites and reveals a contrast between montane Potamites being restricted to upper basins from Central Bolivia to Central Peru, and lowland species being widespread across the Amazon Basin in Ecuador, Peru, Brazil, and southern Colombia (Uzzell 1966; Avila-Pires 1995; Ribeiro-Júnior \& Amaral 2016, 2017). Despite geographic barriers (i.e., Apurimac River for P. montanicola, Inambari River for P. erythrocularis) separating the distribution ranges of montane species, both montane species share a similar keeling phenotype, whereas populations of the 'lowland keeling phenotype' are widely distributed in the Amazon basin. We hypothesize that adaptation to stronger torrents through the convergent evolution of the dorsal keels pattern occurred repeatedly as lowland Potamites colonized montane environments. Indeed, previous genetic data support the hypothesis that Potamites lizards are closely related to nonriparian Andean taxa such as Dendrosauridion Lehr, Moravec, Lundberg, Köhler, Catenazzi \& Šmíd, 2020 and Selvasaura Moravec, Šmid, Štundl \& Lehr, 2018 (Moravec et al. 2018; Fang et al. 2020; Vasquez-Restrepo et al. 2020). The ancestor of Potamites may be a non-riparian lineage that evolved the crocodile-like morphology (Marques-Souza et al. 2018) after colonizing riparian micro habitats during the formation of the Pebas Lake in the Miocene (Marques-Souza et al. 2018). Thus, the hypothesis of an earlier Andean origin (Torres-Carvajal et al. 2016) with subsequent dispersions to the Amazon lowlands and late mountains re-colonization (Patton et al. 2000; Roberts et al. 2006; Brown \& Twomey 2009; Upham et al. 2013; Torres-Carvajal et al. 2016; French et al. 2019; Guillory et al. 2019) is consistent with current diversity and distribution patterns for species of Potamites in the Andes. Nonetheless, 


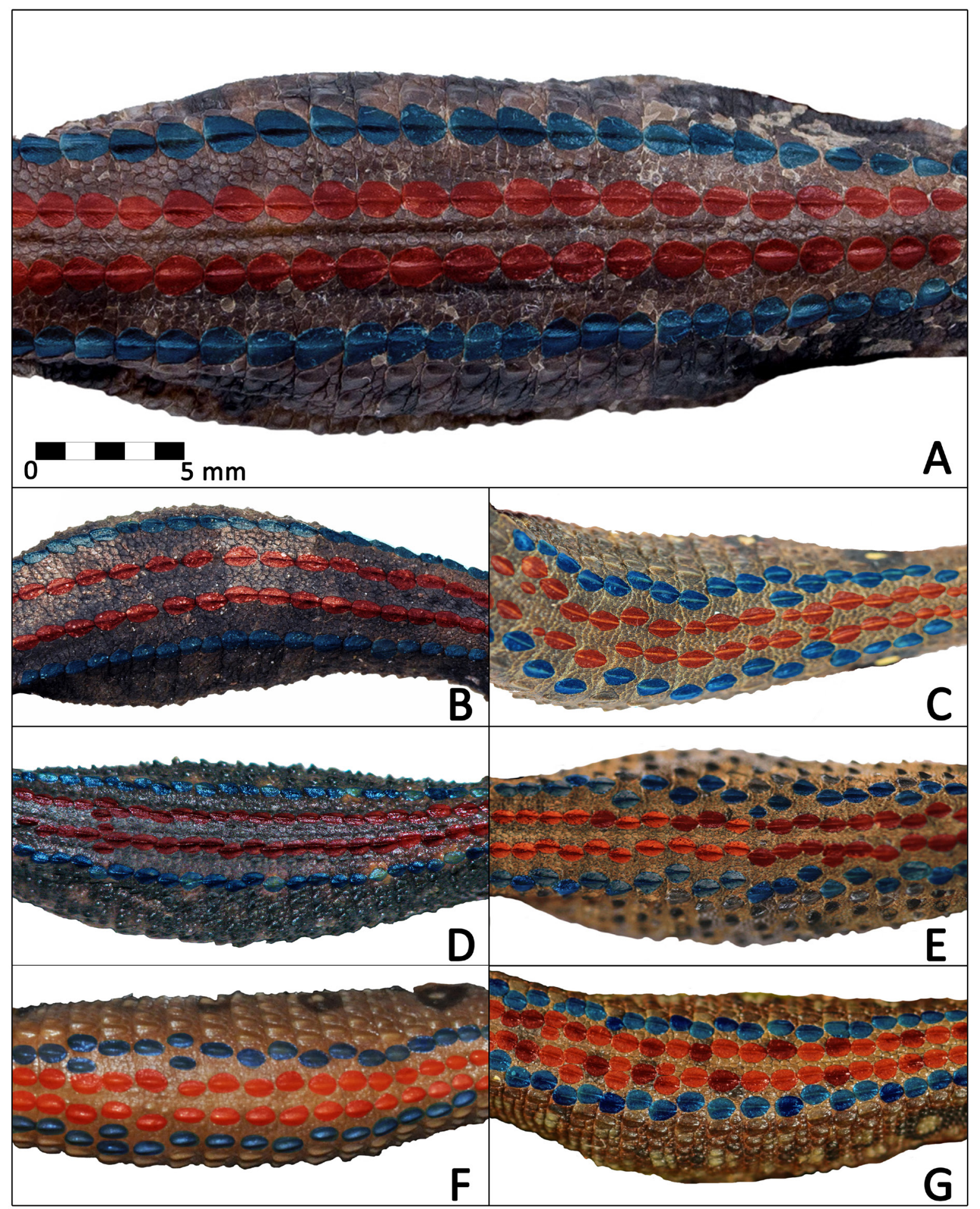

Fig. 7. Keeled dorsum in species of Potamites Doan \& Castoe, 2005 showing the pattern of the dorsolateral keeled rows (blue) and paravertebral keeled rows (red). A. P. hydroimperator sp. nov. (CORBIDI 13915, holotype). B. P. ecpleopus Cope, 1875 (CORBIDI 11338). C. P. erythrocularis Chávez \& Catenazzi, 2014 (CORBIDI 21841). D. P.juruazensis Avila-Pires \& Vitt, 2001 (MPEG 17775, holotype). E. P. montanicola Chávez \& Vasquez, 2012 (CORBIDI 8322, holotype). F. P. ocellatus Sinitsin, 1930 (AMNH 22512, holotype). G. P. trachodus Uzzell, 1966 (CORBIDI 15515). 


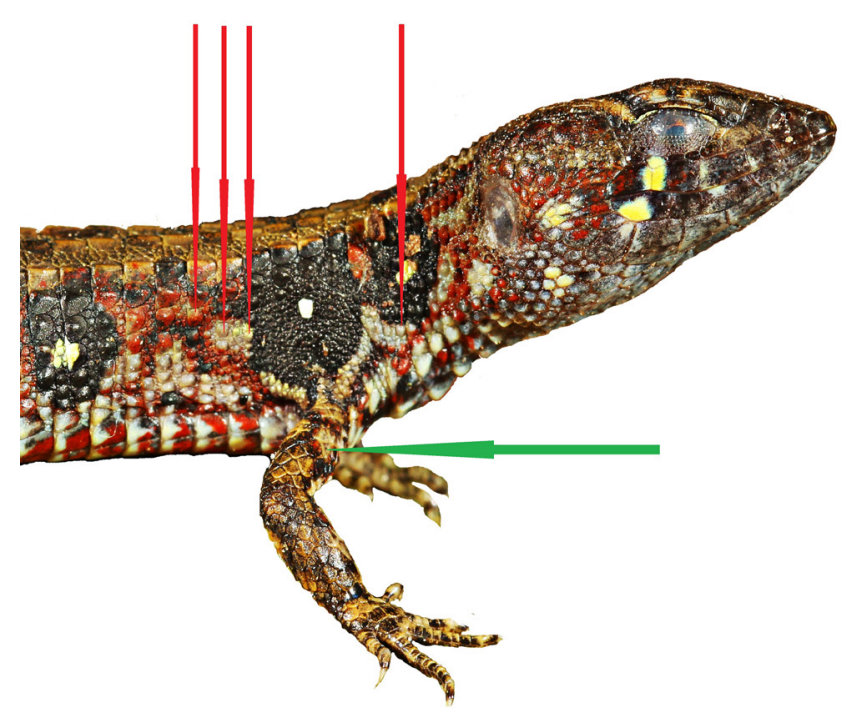

\section{A}
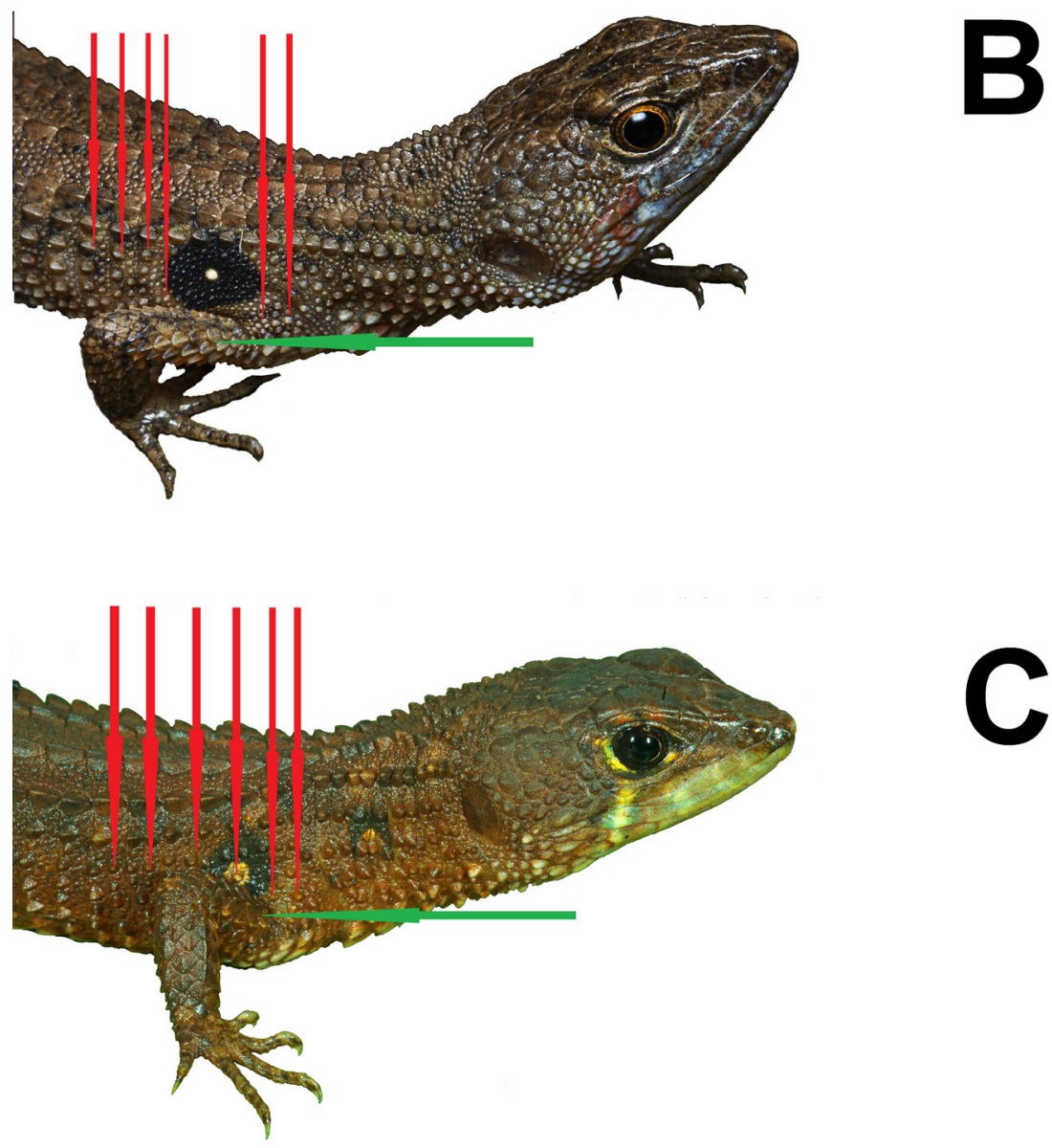

Fig. 8. Lateral views comparing the condition of tubercles on flanks and sides of the neck (red arrows) and anterodorsal scales on limbs (green arrows). A. Potamites hydroimperator sp. nov. (paratype $\widehat{\delta}$, CORBIDI 14468). B. P. ecpleopus Cope, 1875 (uncollected $\widehat{~}$ ) from Yurimaguas. C. P. ecpleopus Cope, 1875, ô (CORBIDI 9516) from Cerros de Kampankis. Photographs by Germán Chávez (A), Angel Chujutalli (B) and Alessandro Catenazzi (C). 
additional molecular analyses focused on the diversification of Potamites are necessary to test alternative biogeographic hypotheses.

The type locality of $P$. hydroimperator sp. nov. lies on a mountain ridge that has been recognized as a likely harbour of unknown fauna (Duellman \& Toft 1979). Every herpetological survey performed in these mountains has discovered new species (Duellman \& Toft 1979; Torres-Carvajal et al. 2016; Brown et al. 2019). The accidented topography, and the presence of a single trail into the El Sira Communal Reserve, explains why only a handful of scientific expeditions have been able to reach the highest elevations of these mountains. We believe that our knowledge of this area is still far from being complete. Future fieldwork should focus on opening new trails to the top of El Sira Mountains, in order to increase our understanding of the herpetofauna inhabiting these forests.

In spite of the type locality of $P$. hydroimperator sp. nov. lying inside a protected area, during our fieldwork we observed illegal gold mining activity near one of the spots where we recorded the new species. Gold mining occurred in the lower reaches of the streams that are flowing down to the Pachitea River, whereas the new species inhabits the upper reaches of these streams. Nonetheless, the establishment of mining camps causes large forest clearings, which could affect the habitat of the new species. Strikingly, expeditions to the eastern slopes of El Sira have not found $P$. hydroimperator sp. nov. (GC unpublished data). Following the IUCN Red List Categories and Criteria (IUCN 2001), considering that the aforementioned threat could eventually cause habitat fragmentation and degradation, the known distribution of $P$. hydroimperator sp. nov. includes only two very close localities in the same mountain (no more than $4 \mathrm{~km}$ far), and the possible Area of Occupancy (AOO) is not wider than $6000 \mathrm{~km}^{2}$ (which is the entire extension of the El Sira Communal Reserve (SERNANP 2010), we provisionally assess this species as Vulnerable (VU) under criteria B2ab(iii).

\section{Acknowledgements}

We thank Marco A. Ribeiro-Júnior and an anonymous reviewer for their valuable feedback and insightful comments on the earliest version of this manuscript. This research would not have been possible without the support of Deutsche Gesellschaft für Internationale Zusammenarbeit (GIZ) that trusted GC to perform the fieldwork. We are deeply grateful to the staff of the Servicio Nacional de Áreas Naturales Protegidas (SERNANP) for granting us the collection permits and supporting our work inside El Sira Communal Reserve. We also thank Milagros Toala and Katherine Toepfer for logistic support and for their valuable help during fieldwork. We thank Lauren Vonnahme and David Kizirian (AMNH) for their assistance with providing photographs of specimens under their care and Angel Chujutalli for provide photographs of the specimen from Yurimaguas.

\section{Contributions of the authors}

Design of the study: GC, JM; collecting specimens specifically for this project: GC, JM; identification of specimens: GC, JM; analysis of the genetic data: AC; analysis of morphological data and writing of the manuscript: GC, JM, AC; comment and discussion of the manuscript: GC, JM, AC.

\section{References}

Avila-Pires T.C.S. 1995. Lizards of Brazilian Amazonia (Reptilia: Squamata). Zoologische Verhandelingen 299 (1): 1-706.

Avila-Pires T.C.S. \& Vitt L. 1998. A new species of Neusticurus (Reptilia: Gymnophtalmidae) from the Río Juruá, Acre, Brazil. Herpetologica 54 (2): 235-245. 
Brown J.L., Siu-Ting K., von May R., Twomey E., Guillory W.X., Deutsch M.S. \& Chávez G. 2019. Systematics of the Ameerega rubriventris complex (Anura: Dendrobatidae) with descriptions of two new cryptic species from the East-Andean versant of Peru. Zootaxa 4712 (2): 211-235.

https://doi.org/10.11646/zootaxa.4712.2.3

Brown J.L. \& Twomey E.M. 2009. Complicated histories: Three new species of poison frogs of the genus Ameerega (Anura: Dendrobatidae) from north-central Peru. Zootaxa 2049 (1): 1-38. https://doi.org/10.11646/zootaxa.2049.1.1

Chávez G. \& Catenazzi A. 2014. A new Andean lizard of the genus Potamites (Sauria, Gymnophtalmidae) from Manu National Park, southeastern Peru. Zootaxa 3774 (1): 45-56.

https://doi.org/10.11646/zootaxa.3774.1.3

Chávez G. \& Vásquez D. 2012. A new species of Andean semiaquatic lizard of the genus Potamites (Sauria, Gymnophthalmidae) from southern Peru. ZooKeys 168: 31-43.

https://doi.org/10.3897/zookeys.168.2048

Cope E.D. 1875. Report on the reptiles brought by Professor James Orton from the middle and upper Amazon and western Peru. Journal of the Academy of Natural Sciences of Philadelphia N.S. 8 (2): $159-183$.

de Queiroz K. 1998. The general lineage concept of species, species criteria, and the process of speciation. In: Howard D.J. \& Berlocher S.H. (eds) Endless Forms: Species and Speciation: 57-75. Oxford University Press, Oxford.

de Queiroz K. 2007. Species concepts and species delimitation. Systematic Biology 56: 879-886. https://doi.org/10.1080/10635150701701083

Duellman W.E. \& Toft C. 1979. Anurans from the Serranía de Sira, Amazonian Perú: Taxonomy and Biogeography. Herpetologica 35: 60-70. Available from https://www.jstor.org/stable/3891754 [accessed 13 Jul. 2021].

Dueñas M. \& Valencia J. 2018. Bothrocophias microphtalmus (Small-eyed Toas-headed Pitviper). Habitat use and diet. Herpetological Review 49 (3): 542.

Fang J.M., Vásquez-Restrepo J.D. \& Daza J.M. 2020. Filling the gaps in a highly diverse Neotropical lizard lineage: a new endemic genus of Cercosaurinae (Squamata: Gymnophtalmidae) with the description of two new species from the Northern Andes of Colombia. Systematic and Biodiversity 18 (5): 417-433. http://doi.org/10.1080/14772000.2020.1783714

French C.M., Deutscha M.S., Chávez G., Almora C.E. \& Brown J.L. 2019. Speciation with introgression: phylogeography and systematics of the Ameeregea petersi group (Familiy Dendrobatidiae). Molecular Phylogenetics and Evolution 138: 31-42. https://doi.org/10.1016/j.ympev.2019.05.021

Goicoechea N., Padial J.M., Chaparro J.C., Castroviejo-Fisher S. \& De la Riva I. 2012. Molecular phylogenetics, species diversity, and biogeography of the Andean lizards of the genus Proctoporus (Squamata: Gymnophthalmidae). Molecular Phylogenetics and Evolution 65: 953-964.

https://doi.org/10.1016/j.ympev.2012.08.017

Goicoechea N., Padial J.M., Chaparro J.C., Castroviejo-Fisher S. \& De la Riva I. 2013. A taxonomic revision of Proctoporus bolivianus Werner (Squamata: Gymnophthalmidae) with the description of three new species and resurrection of Proctoporus lacertus Stejneger. American Museum Novitates 3786: 1-32. https://doi.org/10.1206/3786.1

Guillory W., French C.M., Twomey E.M., Chávez G., Prates I., von May R., De la Riva I., Lötters S., Reichle S., Serrano-Rojas S.J., Whitworth A. \& Brown J.L. 2020. Comprehensive phylogenomic 
reconstruction of the Amazonian poison frog genus Ameerega using ultraconserved elements. Molecular Phylogenetics and Evolution 142: 106638. https://doi.org/10.1016/j.ympev.2019.106638

IUCN. 2001. IUCN Red List Categories and Criteria: Ver. 3.1. IUCN, Gland / Cambridge. Available from https://portals.iucn.org/library/sites/library/files/documents/RL-2001-001.pdf [accessed 7 Jul. 2021].

Köhler G. \& Lehr E. 2004. Comments on Euspondylus and Proctoporus (Squamata: Gymnophthalmidae) from Peru, with the description of three new species and a key to the Peruvian species. Herpetologica 60: 501-518. https://doi.org/10.1655/03-93

Kok P.J.R., Bittenbinder M.A., van den Berg J.K., Marques-Souza S., Nunes P.M.S., Laking A.E., Teixeira M. Jr., Fouquet A., Means D.B., MacCulloch R.D. \& Rodrigues M.T. 2018. Integrative taxonomy of the Gymnophtalmid lizard Neusticurus rudis Boulenger, 1900 identifies a new species in the Pantepui region, north-eastern South Africa. Journal of Natural History 52 (13): 1029-1066.

https://doi.org/10.1080/00222933.2018.1439541

Marques-Souza S., Prates I., Fouquet A., Camacho A., Kok P.J.R., Nunes P.M.S., Dal Vechio F., Souza Recoder R., Mejia N., Teixeira M. Jr., Barrio-Amorós C., Cassimiro J., Dias-Lima J., de Sena M.A. \& Rodrigues M.T. 2018. Reconquering the water: Evolution and systematics of South and Central American acuatiq lizards (Gymnophtalmidae). Zoologica Scripta 47: 255-265. https://doi.org/10.1111/zsc.12273

Moravec J., Šmíd J., Štundl J. \& Lehr E. 2018. Systematic of Neotropical microteiid lizards (Gymnophtalmidae, Cercosaurinae), with the description of a new genus and species from the Andean montane forests. ZooKeys 774: 105-139. https://doi.org/10.3897/zookeys.774.25332

Paradis E., Claude J. \& Strimmer K. 2004. APE: Analyses of Phylogenetics and Evolution in R language. Bioinformatics 20: 289-290. https://doi.org/10.1093/bioinformatics/btg412

Patton J.L., da Silva M.N.F. \& Malcolm J.R. 2000. Mammals of the Rio Juruá and the evolutionary and ecological diversification of the Amazonia. Bulletin of the American Museum of the Natural History 244: 1-306. https://doi.org/d9f7q9

Pellegrino K.C.M., Rodrigues M.T., Yonenaga-Yassuda Y. \& Sites Jr. J.W. 2001. A molecular perspective on the evolution of microteiids lizards (Squamata, Gymnophtalmidae) and a new classification for the family. Biological Journal of the Linnean Society 74 (3), 315-338.

https://doi.org/10.1111/j.1095-8312.2001.tb01395.x

Ratnasingham S. \& Hebert P.D.N. 2007. BOLD: The Barcode of Life Data System. Molecular Ecology Notes 7: 355-364. https://doi.org/10.1111/j.1471-8286.2007.01678.x

Ribeiro-Júnior M. \& Amaral S. 2016. Diversity, distribution and conservation of lizards (Reptilia, Squamata) in the Brazilian Amazonia. Neotropical Biodiversity 2 (1): 194-421.

https://doi.org/10.1080/23766808.2016.1236769

Ribeiro-Júnior M. \& Amaral S. 2017. Catalogue of distribution of lizards (Reptilia, Squamata) from the Brazilian Amazonia. IV. Alopoglossidae, Gymnophtalmidae. Zootaxa 4269 (2): 151-196.

https://doi.org/10.11646/zootaxa.4269.2.1

Roberts J.L., Brown J.L., von May R., Arizábal W., Schulte R. \& Summers K. 2006. Genetic divergence and speciation in lowland montane Peruvian poison frogs. Molecular Phylogenetics and Evolution 41: 149-164. http://doi.org/10.1016/j.ympev.2006.05.005

Sánchez-Pacheco S.J., Torres-Carvajal O., Aguirre-Peñafiel V., Nunes P.M.S., Verrastro L., Rivas G.A., Rodrigues M.T., Grant T. \& Murphy R.W. 2018. Phylogeny of Riama (Squamata: Gymnophthalmidae), impact of phenotypic evidence on molecular datasets, and the origin of the Sierra Nevada de Santa Marta endemic fauna. Cladistics 34 (3): 260-291. https://doi.org/10.1111/cla.12203

SERNANP. 2010. Guía Oficial de Áreas Naturales Protegidas del Perú. Sernanp \& Profonanpe, Lima. 
Torres-Carvajal O., Echevarría L.Y., Venegas P.J., Chávez G. \& Camper J.D. 2015. Description and phylogeny of three new species of Synophis (Colubridae, Dipsadinae) from the Tropical Andes in Ecuador and Peru. ZooKeys 546: 153-179. http://doi.org/10.3897/zookeys.546.6533

Torres-Carvajal O., Lobos S.E., Venegas P.J., Chávez G., Aguirre-Peñafiel V., Zurita D. \& Echevarría L.Y. 2016. Phylogeny and biogeography of the most diverse clade of South American gymnophthalmid lizards (Squamata, Gymnophthalmidae, Cercosaurinae). Molecular Phylogenetics and Evolution 99: 63-75. https://doi.org/10.1016/j.ympev.2016.03.006

Upham N.S., Ojala-Barbour R., Brito J., Velazco P.M. \& Patterson B.D. 2013. Transitions between Andean and Amazonian centers of endemism in the radiation of some arboreal rodents. BMC Evolutionary Biology 13: 191. https://doi.org/10.1186/1471-2148-13-191

Uzzell T.M. 1966. Teiid lizards of the genus Neusticurus (Reptilia:Sauria). Bulletin of the American Museum of Natural History 132: 227-377.

Vásquez-Restrepo J.D., Ibáñez R., Sánchez-Pacheco S.J. \& Daza J.M. 2020. Phylogeny, taxonomy, and distribution of the Neotropical lizard genus Echinosaura (Squamata: Gymnophtalmidae), with the recognition of two new genera in Cercosaurinae. Zoological Journal of the Linnean Society 189: 287-314.

https://doi.org/10.1093/zoolinnean/zlz124

Vanzolini P.E. 1995. Neusticurus ocellatus, 1930: A valid species of teiid lizard from Bolivia. American Museum Novitates 3123: 1-7.

Zaher H. 1999. Hemipenial morphology of the South American xenodontine snakes, with a proposal for a monophyletic Xenodontinae and a reappraisal of colubroid hemipenes. Bulletin of the American Museum of Natural History 240: 1-168.

Manuscript received: 15 October 2020

Manuscript accepted: 24 May 2021

Published on: 23 July 2021

Topic editor: Rudy C.A.M. Jocqué

Desk editor: Radka Rosenbaumová

Printed versions of all papers are also deposited in the libraries of the institutes that are members of the EJT consortium: Muséum national d'histoire naturelle, Paris, France; Meise Botanic Garden, Belgium; Royal Museum for Central Africa, Tervuren, Belgium; Royal Belgian Institute of Natural Sciences, Brussels, Belgium; Natural History Museum of Denmark, Copenhagen, Denmark; Naturalis Biodiversity Center, Leiden, the Netherlands; Museo Nacional de Ciencias Naturales-CSIC, Madrid, Spain; Real Jardín Botánico de Madrid CSIC, Spain; Zoological Research Museum Alexander Koenig, Bonn, Germany; National Museum, Prague, Czech Republic.

\section{Supplementary files}

Supp. file 1: Uncorrected genetic distances ( $p$-distances) between Potamites hydroimperator $\mathrm{sp}$. nov. and other congeners. Values based on the $12 \mathrm{~S}$ alignment. Values for the new species are in bold. https://doi.org/10.5852/ejt.2021.760.1445.4735 
Supp. file 2: Uncorrected genetic distances (p-distances) between Potamites hydroimperator sp. nov. and other congeners. Values based on the $16 \mathrm{~S}$ alignment. Values for the new species are in bold. https://doi.org/10.5852/ejt.2021.760.1445.4737

Supp. file 3: Uncorrected genetic distances (p-distances) between Potamites hydroimperator sp. nov. and other congeners. Values based on the ND4 alignment. Values for the new species are in bold. https://doi.org/10.5852/ejt.2021.760.1445.4739

Supp. file 4: Uncorrected genetic distances (p-distances) between Potamites hydroimperator sp. nov. and other congeners. Values based on the c-mos alignment. Values for the new species are in bold. https://doi.org/10.5852/ejt.2021.760.1445.4741

Supp. file 5: Close up of the hemipenis of the holotype of Potamites hydroimperator sp. nov. (CORBIDI 13915).

https://doi.org/10.5852/ejt.2021.760.1445.4743 
Appendix 1. Additional specimens examined.

\section{Potamites ecpleopus}

BRASIL - Amazonas • Igarape Belem, near Rio Solimoes, ca $70 \mathrm{~km}$ E of Leticia; AMNH 114983 to 114986.

COLOMBIA - Putumayo • Quebrada Lorena; SINCHI 0755.

ECUADOR - Orellana • Estación Científica PUCE Parque Nacional Yasuní; QCAZR 6361 • Vía Pompeya Sur-Iro; QCAZR 8037. - Pastaza 5 km al norte de Puyo via al Tena, Hosteria Safari; QCAZR 7610. - Sucumbios • Rio Reventador; QCAZR 8926.

PERU - Amazonas - Condorcanqui, Cordillera de Kampankis; CORBIDI 09436, 9480, 09509, 09516, 11338, 11339. - Cusco • La Convencion, Comunidad Nativa Tangoshiari; CORBIDI 0311-13・ Pongo de Mainique- Santuario Nacional Megantoni; CORBIDI 05519 • Campamento Kinteroni; CORBIDI 06992, 06993, 06997 • Comunidad Nativa Monte Carmelo; CORBIDI 08331.33 • Comunidad Nativa Chokoriari; CORBIDI 08498 08499. - Junin - Satipo, Portillo Alto - Fundo Santa Teresa; CORBIDI 15830, 15868, 15869, 16825, 16828, 16829. - Loreto • Datem del Marañon, Andoas; CORBIDI 01077, 04637, 04641 to $04643,04746,04751,04981,05056 \cdot$ Quebrada Wee; CORBIDI 09563 to 09567, 09576 to $09578 \cdot$ San Jacinto; CORBIDI 01208, $1209 \cdot$ Singasapa; CORBIDI 06529 • Rio Corrientes; CORBIDI 02731 • Río Yanayacu; CORBIDI 05989 • Putumayo, Aguas Negras; CORBIDI 0280 • Redondococha; CORBIDI 0286 • Requena, Sierra del Divisor; CORBIDI 02246 to 02248, 02585, 04138, 04144. - San Martin • Achinamisa, Valle del río Huallaga; AMNH 56381 • Chazuta, E de Tarapoto, río Huallaga 56247, Moyobamba, Comunidad Morro de Calzada; CORBIDI 01360 • Lamas, Pongo de Caynarachi; CORBIDI 09059 • Pachiza, Río Huayabamba, trib. Del río Huallaga; AMNH 56226, 56234, 56247 • Río Caynarachi, trib. Del río Huallaga; AMNH 56392.

\section{Potamites erythrocularis}

PERU - Cusco • Paucartambo, Quebrada San Pedro; CORBIDI 11484, 11485, 16228, 16317, 16318 - Quispicanchi, Capire; CORBIDI 14354, 14356, 14357. - Madre de Dios • Tambopata, El Parador; CORBIDI 13547, 13548• Corredor Manu-Tambopata; CORBIDI 15152 to 15153.

\section{Potamites juruazensis}

PERU - Cusco • La Convención, Pagoreni Norte; CORBIDI 10004, 10026. - Huánuco • Puerto Inca, Puerto Inca; CORBIDI 14985, 16723, 16726. - Ucayali • Coronel Portillo, Río Abujao; CORBIDI 12970, 13010, 13073.

\section{Potamites montanicola}

PERU - Ayacucho - La Mar, Carretera Chiquintirca - San Antonio; CORBIDI 6957. - Cusco • La Convención, Comunidad Nativa de Poyentimari; CORBIDI 8322, 8324, 8328, 8334, 8335.

\section{Potamites ocellatus}

BOLIVIA - Beni • Rurrenabaque; AMNH 22512.

\section{Potamites strangulatus}

PERU - Amazonas • Condorcanqui, Cordillera de Kampankis; CORBIDI 11415, 11419. - Loreto • Datem del Marañon, Pongo Chinim; CORBIDI 9352, 9397, 9399, 9411 • Quebrada Wee; CORBIDI $09523,09524$. 


\section{Potamites trachodus}

PERU - Amazonas • Bagua, Chonza Alta; CORBIDI 0739 to 070744. - Cajamarca • San Ignacio, Alto Ihuamaca; CORBIDI 0878 to 0880. - Huánuco • Huánuco, Chinchavito; CORBIDI 9304 • Río Huallaga; CORBIDI 16408, 16410, 16411, 16417, 16418, 16427, 16442 • Leoncio Prado, Parque Nacional Tingo María-La Garganta CORBIDI 15479, 15514, 15515 • Pachitea, Río Huallaga; CORBIDI 16570, 16571 • Santa Clara, CORBIDI 14926, 14929 to 14931. - San Martín • Moyobamba, Comunidad Nativa Paitoja; CORBIDI 01237 to 01241, 01262, 01263, 03145, 03147, 03192 • Fundo Pabloyacu; CORBIDI 01392 - Moyobamba, Zona Reservada Miskiyaku; CORBIDI 01429 to 01430, 01434, 01437, 01441, 03274 to 03275 • San Martín, Cordillera Escalera; CORBIDI 06366 to 06369, 06383, 06773. 
CHÁVEZ G. et al., A new riparian lizard (Gymnophtalmidae, Potamites) from Peru

Appendix 2. Novel sequences obtained during this study.

\begin{tabular}{lccccc}
\hline \multirow{2}{*}{ Species } & \multirow{2}{*}{ Voucher code } & \multicolumn{4}{c}{ Genbank Accesion } \\
\cline { 3 - 6 } & & 12S & 16S & c-mos & ND4 \\
\hline Potamites ecpleopus & CORBIDI 11339 & MW 940958 & MW 811443 & MW 965467 & MW 965469 \\
Potamites ecpleopus & CORBIDI 11460 & MW 940959 & MW 811444 & MW 965468 & - \\
\hline
\end{tabular}

